\title{
Alpha-actinin of the chlorarchiniophyte Bigelowiella natans
}

\author{
Lars Backman Corresp. 1 \\ 1 Department of Chemistry, Umeå University, Umeå, Sweden \\ Corresponding Author: Lars Backman \\ Email address: lars.backman@chem.umu.se
}

The genome of the chlorarchiniophyte Bigelowiella natans codes for a protein annotated as an $\alpha$-actinin-like protein. Analysis of the primary sequence indicate that this protein has the same domain structure as other $\alpha$-actinins. A N-terminal actin-binding domain and a Cterminal calmodulin-like domain. These two domains are connected by a short rod domain, albeit long enough to form a single spectrin repeat. To analyse the functional properties of this protein, the full- length protein as well as the separate domains were cloned and isolated. Characerisation showed that the protein is capable of cross-linking actin filaments into dense bundles, probably due to dimer formation. Similar to human $\alpha$-actinin, calciumbinding occurs to the most N-terminal EF-hand motif in the calmodulin-like C-terminal domain. The results indicate that this Bigelowiella protein is a proper $\alpha$-actinin, with all common characteristics of a typical $\alpha$-actinin. 
2

3

4

5

6

7

8

9

10

11 Correspondence to:

12 Lars Backman

13 Department of Chemistry, Umeå University, SE-901 87 Umeå, Sweden

14 Telephone: +46 - 907865847

15 Fax: $+46-907867655$

16 e-mail: lars.backman@chem.umu.se

17

18

\section{Bigelowiella natans}

\author{
Lars Backman \\ Departments of Chemistry \\ Umeå University \\ SE-901 87 Umeå, Sweden
}




\section{Abstract}

20 The genome of the chlorarchiniophyte Bigelowiella natans codes for a protein annotated as an $\alpha$ 21 actinin-like protein. Analysis of the primary sequence indicate that this protein has the same

22 domain structure as other $\alpha$-actinins. A N-terminal actin-binding domain and a C-terminal

23 calmodulin-like domain. These two domains are connected by a short rod domain, albeit long

24 enough to form a single spectrin repeat. To analyse the functional properties of this protein, the

25 full- length protein as well as the separate domains were cloned and isolated.

26 Characerisation showed that the protein is capable of cross-linking actin filaments into dense

27 bundles, probably due to dimer formation. Similar to human $\alpha$-actinin, calcium-binding occurs to

28 the most N-terminal EF-hand motif in the calmodulin-like C-terminal domain. The results

29 indicate that this Bigelowiella protein is a proper $\alpha$-actinin, with all common characteristics of a

30 typical $\alpha$-actinin.

31

32 


\section{1. Introduction}

34 The cellular cytoskeleton is indispensable for any eukaryotic cell. This protein network,

35 composed to varying degrees of actin filaments, intermediate filaments and microtubules, plays a

36 role in all cellular events. The organisation and dynamics of the actin cytoskeleton is regulated

37 by a variety of actin-binding proteins and other accessory proteins (Dos Remedios et al. 2003;

38 McGough 1998; Winder \& Ayscough 2005). One such accessory protein is $\alpha$-actinin, that due to

39 its ability to form antiparallel dimers is capable to cross-link actin filament into fibers or bundles

40 as well as networks (Foley \& Young 2014; Wachsstock et al. 1993).

$41 \alpha$-actinin, like other members of the spectrin superfamily, is characterised by three structural

42 domains: a N-terminal actin-binding domain, composed of two calponin homology domains, and

43 a C-terminal calmodulin-like domain (Broderick \& Winder 2005; Wasenius et al. 1987). These

44 domains are connected by a central rod domain consisting of spectrin-like repeats (Blanchard et

45 al. 1989; Otey \& Carpen 2004; Sjöblom et al. 2008). Depending on the source of $\alpha$-actinin, the

46 rod domain contains one, two or four spectrin repeats. Vertebrate and invertebrate $\alpha$-actinins

47 have a rod with four repeats whereas $\alpha$-actinin of fungal origin contains only two repeats (Virel

48 \& Backman 2004; Virel \& Backman 2007). Some protozoa, like Entamoeba histolytica and

49 Encephalitozoon cuniculi have a much shorter rod sequence, that may form a single repeat but

50 more likely fold into a coiled-coil region (Virel \& Backman 2004). Plants, algea and other

51 photosynthesising organisms seem to lack $\alpha$-actinin or $\alpha$-actinin-like proteins. Therefore, it was

52 surprising that the genome of the photosyntesising chlorarachniophyte Bigelowiella natans

53 (Neilson et al. 2017) contains a gene that is annotated as a $\alpha$-actinin-like protein (Curtis et al.

54 2012). No other members of the spectrin superfamily appears to be present in Bigelowiella.

55 Chlorarachniophytes are believed to have arisen through a secondary endosymbiosis when a

56 green algae (a chlorophyte) was engulfed by a non-photosyntesising eukaryotic host (Archibald

57 et al. 2003; Curtis et al. 2012; Gould et al. 2008; Neilson et al. 2017; Rogers et al. 2004).

58 Chlorarachniophytes have genetic material at four distinct locations; in the nucleus, 
59 mitochondria, plastid and nucleomorph, the remnant genome of the engulfed green algae (Curtis

60 et al. 2012). Only a small number of genes (331) remains in the nucelomorph as most have been

61 transferred to the nucleus or lost. (Gilson et al. 2006). As present day green algaes lack $\alpha$-actinin

62 or $\alpha$-actinin-like proteins, it is likely that the gene was already present in the genome of the host.

63 According to the JGI genome portal, the genome of Bigelowiella contain 610 gene models

64 considered to be cytoskeletal. In addition to $\alpha$-actinin, homologues of common actin-binding

65 proteins are present; such as Arp2/3, filamin, gelsolin and many more. Recently, the evolution of

66 key elements of the Chlorarachniophyte cytoskeleton in relation to the other Rhizaria phyla

67 Foraminifera and Radiolariain were described (Krabberød et al. 2017). It was suggested that

68 pseudopodia of Chlorarachniophytes rely on actin structures whereas those of Foraminifera and

69 Radiolariain are dependent on microtubules. In vertebrates, $\alpha$-actinin is involved in the

70 attachment of actin filaments to membranes as well as in filopodia and lamellipodia formation

71 (Geiger et al. 1984; Hamill et al. 2015; Sobue \& Kanda 1989; Wehland et al. 1979). If the

72 Bigelowiella $\alpha$-actinin-like protein is a genuine $\alpha$-actinin, it can be expected to have similar

73 functions also in this organism. To investigate this, the Bigelowiella $\alpha$-actinin-like protein and its

74 structural domains were cloned, expressed in bacteria, isolated and characterized.

75 To my knowledge this is the first report on cloning, expression, isolation and characterisation of

76 a Bigelowiella protein.

\section{2. Materials and methods}

\subsection{Cloning, expression and purification}

The sequence of $B$. natans $\alpha$-actinin was obtained from Joint Genome Institute (JGI), accession number 89463 . To facilitate subcloning the N-terminal methionine, was removed and BamHI and XhoI restriction sites were added to the 5'- and 3'-end, respectively. The final gene was

82 synthesized and inserted in plasmid pUC57 by Genscript (Piscataway, New Jersey, USA). The

83 resulting plasmid pUC57-BigN-ACTN was used to transform (by heat shock) competent E. coli

84 TG1 cells. After over-night culture at $37^{\circ} \mathrm{C}$ in Luria-Bertani medium containing $100 \mu \mathrm{M}$ 
85 carbenicillin, plasmids were isolated using QIAprep Spin miniprep kit (Qiagen GmbH, Hilden,

86 Germany). The $\alpha$-actinin gene was excised by Bam HI and XhoI, gel purified and ligated into

87 pET-TEV (a modified pET-19b vector) containing an N-terminal 10xHis-tag and a TEV protease

88 cleavage site. The resulting plasmid pTEV-BigN-ACTN was then used to transform (by heat

89 shock) competent E. coli BL21(DE3).

90 Breakpoints for the structural domains of $B$. natans $\alpha$-actinin were determined by alignment with

91 other $\alpha$-actinins as well as the database Superfamily (Wilson et al. 2009). When Smart (Letunic

92 et al. 2015) and Pfam (Finn et al. 2016) were interrogated with the amino acid sequence of $B$.

93 natans $\alpha$-actinin similar domain assignments were returned (Table 1). As shown in Figure 1, the

94 expressed full length $B$. natans $\alpha$-actinin contains residues 2 to 524 . The actin-binding domain

95 (ABD) spans residues 2 to 260, the actin-binding domain with the rod domain (ABD-ROD)

96 spans residues 2 to 372 and the rod domain (ROD) spans residues 257-392. Two constructs of

97 the calmodulin-like domain (EF) were made, the longer construct (EF) contains residues 326 to

98524 and the shorter (short-EF) begin at residue 370.

99 Plasmids expressing ABD, ABD-ROD, ROD and short-EF were created by mutagenesis of

100 pTEV-BigN-ACTN. The gene fragment coding for EF was synthesized by Genscript, and ligated

101 into pET-TEV, as described above, creating plasmid pTEV-BigN-EF.

102 Gene fragments were also inserted in pGEX-6P-2, adding glutathione S-transferse (GST) to the

103 N-terminal instead of the His-tag. This resulted in plasmids pGEX-BigN-ABD, pGEX-BigN-

104 ABD-ROD and pGEX-BigN-EF. To improve purification of expressed proteins, a His-tag (with

1056 His residues) were added to the C-terminal. All constructs were sequenced (Eurofins MWG

$106 \mathrm{GmbH}$, Germany and Genscript, USA) to control the fidelity of the final clones.

107 E. coli BL21(DE3) cells were transformed (by heat-shock) with the purified plasmids containing

108 the different constructs. The transformed cells were cultured at $37^{\circ} \mathrm{C}$ in Luria-Bertani medium

109 containing $100 \mu \mathrm{M}$ carbenicillin until an optical density of 0.6-0.8 at $600 \mathrm{~nm}$ was reached.

110 Protein expression was induced by addition of isopropyl thio- $\beta$-D-galactoside to a final 
111 concentration of $0.5 \mathrm{mM}$ and cells were grown overnight at $16^{\circ} \mathrm{C}$. Cells were harvested by

112 centrifugation $(29,000 \mathrm{xg}$ for $15 \mathrm{~min})$, resuspended in $25 \mathrm{mM}$ sodium phosphate buffer, $\mathrm{pH} 7.6$,

$113150 \mathrm{mM} \mathrm{NaCl}$ and stored at $-20^{\circ} \mathrm{C}$ until the expressed protein was purified.

114 For purification, cells were thawed, polyethyleneimine was added to a final concentration of

$1150.05 \%$ and then lysed by sonication on ice. $1 / 10^{\text {th }}$ volume of $10 \%$ Triton $X-100$ was added to the

116 lysed cells. After 30 min incubation on ice, cell debris was removed by centrifugation at

$11737,000 x g$ for $20 \mathrm{~min}$ and the clarified supernatant loaded on an appropriate column.

118 Clarified supernatant of N-terminal His-tagged proteins were loaded on HiTrap ${ }^{\mathrm{TM}}$ Chelating HP

119 (GE Healthcare Bioscience AB, Sweden) columns charged with nickel. Unbound proteins were

120 eluted with $25 \mathrm{mM}$ sodium phosphate buffer, $\mathrm{pH}$ 7.6, $150 \mathrm{mM} \mathrm{NaCl}, 150 \mathrm{mM}$ imidazole. Bound

121 proteins were eluted with an imidazole gradient ranging from 150 to $500 \mathrm{mM}$ imidazole in the

122 same buffer. Imidazole was removed by gel filtration on HiPrep desalting columns (GE

123 Healthcare Bioscience AB, Sweden). When required, Tobacco Etch Virus (TEV) protease

124 (kindly provided by Dr. David S. Waugh) was used to hydrolyse the His-tag. The released

125 10xHis-tag and the 6xHis-tagged TEV protease were removed by affinity chromatography on a

126 nickel-charged HiTrap ${ }^{\mathrm{TM}}$ Chelating HP as before. To improve solubility, purified proteins were

127 transferred into buffer TK (50 mM Tris, $200 \mathrm{mM} \mathrm{KCl,} \mathrm{pH} \mathrm{8.0)} \mathrm{or} \mathrm{buffer} \mathrm{TKMG} \mathrm{(50} \mathrm{mM} \mathrm{Tris,}$

$128200 \mathrm{mM} \mathrm{KCl}, 10 \mathrm{mM} \beta$-mercaptoethanol, 10\% glycerol, $\mathrm{pH}$ 8.0) by gel filtration on HiPrep

129 desalting columns.

130 GST-tagged proteins were loaded on Glutathione-Sepharose columns (GE Healthcare Bioscience

131 AB, Sweden). After unbound proteins had been eluted bound proteins were eluted with 20-30

$132 \mathrm{mM}$ glutathione in $50 \mathrm{mM}$ Tris, $\mathrm{pH}$ 8.0. The GST-tag was liberated by overnight incubation in

133 the presence of protease C, obtained from the Protein Expert Platform (Sweden). The GST-

134 tagged moiety was removed by a second passage over the Glutathione-Sepharose. As before,

135 purified proteins were transferred into buffer TK or TKMG by gel filtration on HiPrep desalting

136 columns. 
137 GST-free proteins with a C-terminal His-tag were purified further using affinity chromatography

138 on a nickel-charged HiTrap ${ }^{\mathrm{TM}}$ Chelating HP column as described above. The isolated protein

139 was finally transferred into buffer TK or TKMG by gel filtration on a Hiprep 26/10 desalting

140 column.

141 Protein concentration was determined from the absorbance at $280 \mathrm{~nm}$ using the molar

142 absorptivity, as calculated from the amino acid sequence (using ProtParam at the ExPASy

143 proteomics server). The purity of the expressed polypeptides was routinely determined under

144 denaturating conditions by SDS-polyacrylamide gel electrophoresis (Laemmli 1970).

\section{$145 \quad 2.2$ Gel filtration}

146 The propensity of purified polypeptides to form dimers or aggregates were determined by gel

147 filtration on Toyopearl HW50-S 10/300 and Superdex 200 columns. Elution profiles were

148 determined both in buffers TK and TKMG. Since the presence of glycerol affected the elution

149 behaviour, a small volume of dissolved tryptophan was added to each sample as an internal

150 standard and elution profiles were adjusted accordingly.

151 Ferritin (440 kDa) and bovine serum albumin (67 and $135 \mathrm{kDa})$ was used as references.

\section{$152 \quad 2.3$ Actin co-sedimentation assay}

153 Co-sedimentation was used to assay the ability of Bigelowiella $\alpha$-actinin-like protein to cross-

154 link actin. Actin was purified from rabbit skeletal muscle acetone powder as before (Pardee \&

155 Spudich 1982; Spudich \& Watt 1971). Monomeric actin, in $5 \mathrm{mM}$ Tris-HCl, pH 8.0, $0.2 \mathrm{mM}$

$156 \mathrm{CaCl}_{2}$ and $0.2 \mathrm{mM} \mathrm{ATP}$, was polymerised by addition of $\mathrm{KCl}$ and $\mathrm{MgCl}_{2}$ to final concentrations

157 of $50 \mathrm{mM}$ and $2 \mathrm{mM}$, respectively. Actin was allowed to polymerise for $60 \mathrm{~min}$ at room

158 temperature. Polymerised actin was mixed with varying concentrations of full-length

159 Bigelowiella $\alpha$-actinin-like protein and incubated for $30 \mathrm{~min}$ at room temperature. After

160 incubation, the reaction mixture was centrifuged at $13,000 \mathrm{rpm}(16,000 \mathrm{xg})$ for $15 \mathrm{~min}$ and 
161 supernatants and pellets were separated and analysed by SDS-PAGE (Laemmli 1970). The

162 amounts of actin in the pellets were quantified using Image Lab 5.2 (Bio-Rad laboratories).

\subsection{Negative staining electron microscopy}

164 The samples assayed by the co-sedimentation were also analysed by electron microscopy.

165 Copper grids coated with formvar and carbon were prepared with Leica EM ACE200 carbon

166 coating system. Grids were glow-discharged with Pelco easiGlow system (Ted Pella, Inc.). $3.5 \mu 1$

167 sample adsorbed for $2 \mathrm{~min}$, washed twice in water and immediately stained in $50 \mu 11.5 \%$ uranyl

168 acetate solution for 30 seconds. Samples were examined with Talos 120C (FEI, Eindhoven, The

169 Netherlands) operating at 120kV. Micrographs were acquired with a Ceta 16M CCD camera

170 (FEI, Eindhoven, The Netherlands) using TEM Image \& Analysis software ver. 4.15 (FEI,

171 Eindhoven, The Netherlands).

\section{$172 \quad 2.5$ Circular dichroism (CD) spectroscopy}

173 Expressed polypeptides in buffer TK or TKMG with or without urea were analysed by CD

174 spectroscopy using a Jasco J-810 spectrometer. Spectra between 200 and $260 \mathrm{~nm}$ were collected

175 using $0.025 \mathrm{~nm}$ step-size and a scan speed of $50 \mathrm{~nm}$ per min, with a response time of $0.5 \mathrm{sec}$ and

176 a bandwidth of $1 \mathrm{~nm}$. Mean residue molar ellipticity was calculated from three accumulated

177 spectra.

178 The temperature stability of expressed polypeptides was determined by the ellipticity at $222 \mathrm{~nm}$.

179 The thermal scan rate was $1^{\circ} \mathrm{C} / \mathrm{min}$, with a data pitch of $0.2^{\circ} \mathrm{C}, 2 \mathrm{~nm}$ bandwidth and $4 \mathrm{sec}$

180 response time.

\section{$181 \quad 2.6$ Structure prediction}

182 RaptorX (Kallberg et al. 2012; Ma et al. 2013) were used to predict the tertiary structure of 183 separate domains. UCSF Chimera package was used to analyse structures and draw figures 184 (Pettersen et al. 2004). 


\subsection{Calcium assay}

$186{ }^{45} \mathrm{Ca}$ autoradiography was used to determine calcium binding as described (Maruyama et al. 187 1984). Bigelowiella $\alpha$-actinin-like protein was blotted onto a PDVF membrane, wetted with $18860 \mathrm{mM} \mathrm{KCl}, 5 \mathrm{mM} \mathrm{MgCl} 2$, and $10 \mathrm{mM}$ imidazole- $\mathrm{HCl} \mathrm{pH}$ 6.8. The membrane was then incubated 189 in the same solution containing $\sim 50 \mu \mathrm{M}^{45} \mathrm{CaCl}_{2}(20.87 \mathrm{mCi} / \mathrm{mg})$ for $1 \mathrm{~h}$, rinsed with buffer and 190 dried. Autoradiography was used to detect radioactive calcium.

\section{3. Results and discussion}

\section{$192 \quad 3.1$ Cloning, expression and purification}

193 The amino acid sequence of Bigelowiella $\alpha$-actinin-like protein was retrieved from JGI. Based 194 on this amino acid sequence corresponding DNA was synthesised. After subcloning into the expression vector ( $\mathrm{pET}-\mathrm{TEV})$, this plasmid was used as template for preparing constructs of polypeptides used in this report.

197 All constructs expressed well and could be purified by metal chelating chromatography to

198 reasonable purity. However, after removing the imidazole used to release the polypeptides from 199 the metal chelating column, only the two EF peptides were soluble in salt-free buffer $(50 \mathrm{mM}$ 200 Tris, $\mathrm{pH}$ 8.0). All other polypeptides as well as the full-length protein required addition of salt $201(\mathrm{NaCl}$ and/or $\mathrm{KCl})$ to reduce precipitation and aggregation. Although inclusion of $10 \%$ glycerol 202 increased solubility of $\mathrm{ABD}$, still a fraction, that increased with time, precipitated. Independent on the buffer systems tested, it has not been possible to find conditions to keep the polypeptides

204 containing the rod domain, ABD-ROD and ROD, in solution.

\section{Full-length a-actinin-like protein}

After the full-length protein was released from the nickel-column and transferred into a significant fraction was in an aggregated form. 
210 By including a high-speed centrifugation step (343,000xg for $30 \mathrm{~min})$ to remove aggregates

211 before buffer change, no precipitation or aggregation was observed after change to the TKMG

212 buffer. Although soluble, the amount of full-length protein that remained in solution decreased

213 considerable and it degraded with time. When this material was applied on a Superdex 200 gel

214 filtration column, the full-length protein eluted at a position between monomeric and dimeric

215 bovine serum albumin, indicating that no higher oligomers or aggregates were present (Figure

216 2A). The peak that eluted at ca $18 \mathrm{ml}$ (seen as a shoulder in the figure), contained degradation

217 products as seen in Figure 2B.

$218 \boldsymbol{A B D}$

219 Similar to the full-length protein, also ABD displayed a propensity to precipitate when imidazole

220 was removed. Although inclusion of $10 \%$ glycerol and $\beta$-mercaptoethanol increased solubility of

$221 \mathrm{ABD}$, still a fraction, that increased with time, precipitated. When aggregated material was

222 removed by high-speed centrifugation $(343,000 \mathrm{xg}$ for $30 \mathrm{~min})$, monomeric ABD remained in the

223 supernatant as determined by gel filtration. However, upon storage new aggregates formed as

224 shown in Figure 3.

\section{ROD and ABD-ROD}

226 It was not possible to find conditions to keep either of these polypeptides in solution after the

227 initial purification step. Therefore, the properties of these two could not be determined reliably.

\section{EF and short-EF}

229 EF and short-EF could be purified to homogeneity even after cleavage of the N-terminal His-tag 230 used for the initial purification step. Both EF-and short-EF were monomeric even in the absence 231 of salt as determined by gel filtration.

\section{$232 \quad 3.2$ Calcium binding}

233 Initially a ${ }^{45} \mathrm{Ca}$-overlay assay showed that the Bigelowiella full-length $\alpha$-actinin-like protein has

234 affinity for calcium ions as shown in Figure 4. The band intensity indicated that the binding 
235 affinity is similar to that of Entamoeba histolytica $\alpha$-actinin2 ((Virel et al. 2007). To analyse the

236 calcium binding further a CD assay was used. The rationale being that ligand binding will

237 increase the melting temperature of any protein, as the ligand must be dissociated before the

238 protein unfolds and this require more energy, i.e. heat in this case.

239 In all buffers tested, the CD spectra of EF were typical of a folded helical protein, with the 240 typical negative peaks at 208 and $222 \mathrm{~nm}$, independent on whether calcium ions were present or 241 not (Figure 5A). When comparing the melting traces in the absence and presence of calcium of 242 EF and short-EF, only negligible differences were noticeable. It also was evident that the C243 terminal domain was highly stable even at high temperatures. Therefore, in order to destabilize 244 the protein, the denaturant urea was included in the CD measurements. As shown in Figure 5B, 245 increasing concentrations of urea led to increased unfolding of EF in the absence of calcium ions. 246 However, in the presence of calcium ions, EF unfolded only partly. When the melting 247 experiments were repeated in the presence of urea $(\sim 3 \mathrm{M})$, it was evident that calcium stabilised $248 \mathrm{EF}$; in the absence of calcium the melting transition was around $50{ }^{\circ} \mathrm{C}$ whereas addition of 249 calcium increased the transition to around $80^{\circ} \mathrm{C}$ or even higher (Figure 5C). The same results 250 were obtained for shortEF (not shown). These results indicate that the calcium affinity is 251 associated with the calmodulin-like C-terminal and the EF-hand motifs.

252 Superfamily (Wilson et al. 2009) identified residues $372-488$ as an EF-hand domain with a

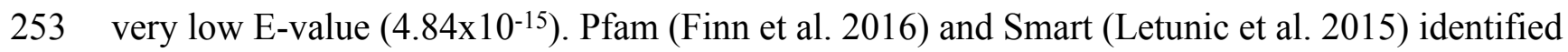
254 residues $392-420$ as an active EF-hand domain (E-values: $2.6 \times 10^{-6}$ and $6.54 \times 10^{-6}$, respectively) 255 and residues $459-520$ as a calcium-insensitive EF-hand domain (E-values: $4.1 \times 10^{-9}$ and $2561.44 \times 10^{-8}$ ). Inspection and alignment to other EF-hand domains and the consensus sequence 257 indicated that only the first EF-hand motif has proper residues in the positions involved in 258 coordinating the calcium ion as Figure 6 shows. The other three motifs lack one or more of the 259 residues believed to be required for calcium binding. 
$260 \quad 3.3$ Actin binding

261 The ability of $\alpha$-actinins to form antiparallel dimers creates binding sites for actin at each end of

262 the dimer, that allows the dimer to cross-link or bundle actin filaments. It is generally believed

263 that the rod domain is required for dimer formation and that the calponin homology domains

264 constitute the binding site for actin. If correct also for the Bigelowiella $\alpha$-actinin-like protein,

265 ABD and ABD-ROD would bind actin filaments but only ABD-ROD would cross-link or bundle

266 filaments, in addition to the full-length protein.

267 The rationale of the co-sedimentaion assay is that cross-linked or bundled actin filaments are

268 pelleted by a low-speed centrifugation whereas any actin binder would only be pelleted with

269 actin filaments by a high-speed centrifugation. Therefore, increasing concentrations of the

270 Bigelowiella $\alpha$-actinin-like protein were incubated with actin filaments before a low-speed

271 centrifugation. As seen in Figure 7A, in the absence of the $\alpha$-actinin-like protein only a very

272 small amount of actin was pelleted. On the other hand, in the presence of increasing

273 concentrations of the full-length $\alpha$-actinin-like protein, increasing amounts of both proteins were

274 found in the pelleted material, indicating cross-linking or bundling of actin. Quantification

275 indicated that a ratio of one cross-linker to two actin monomers were enough for maximal cross-

276 linking (Figure 7B), very similar to the behaviour of Entamoeba histolytica $\alpha$-actinin (Virel et al.

277 2007). As gel filtration indicated that no higher oligomers were present, these results clearly

278 indicate that the $\alpha$-actinin-like protein dimerises.

279 This was corroborated by transmission electron microscopy. In the presence of the Bigelowiella

280 protein actin filaments form networks and bundles, not seen in its absence (Figure 8).

281 Due to the propensity of ABD and ABD-ROD to aggregate and precipitate it was not feasible to

282 investigate their binding further, as even a low-speed spin pelleted most of the ABD-ROD.

283 Likewise, nearly all ABD was found in the pellet after a high-speed centrifugation. 
284 3.4 Homology Modelling

285 The amino acid sequences of ABD, ROD, EF and short EF were submitted to the web server 286 RaptorX for structure predictions (Kallberg et al. 2012; Ma et al. 2013). The qualities of the 287 predicted structures were validated using the Protein Structure Validation Software suite 288 (Bhattacharya et al. 2007). Table 2 shows validation scores for the predicted structures. The 289 scores indicate that the structures are reasonable accurate, with only a few residues in disallowed 290 regions. This is illustrated in Figure 9, by the Ramachandran plot of the ABD model which 291 places 6 residues in disallowed regions (Lys38, Val40, Pro42, Thr14, Pro165 and Val168).

292 One of the templates used in the homology modelling of ABD, was the actin-binding domain of 293 Schizosaccharomyces pombe $\alpha$-actinin. Although the sequence of Bigelowiella ABD is only ca $29439 \%$ identical to the ABD of $S$ pombe (pdb: 5bvr), the DaliLite server (Hasegawa \& Holm 2009) 295 returns a very high Z-score of 32.5 and a low root mean deviation value of $1.0 \AA$. When the Dali 296 server was interrogated with Bigelowiella ABD as query structure, several structures with very

297 high Z-scores and low rmsd values were returned. The returned Z-score of the actin-binding 298 domain of human $\alpha$-actinin3 (pdb: 1wku) and $\alpha$-actinin4 (pdb: 2r0o) were 33.8 and 33.5,

299 respectively, and the rmsd were in both cases $1.0 \AA$. The major structural differences between the 300 predicted structure of Bigelowiella $\mathrm{ABD}$ and determined structure of $S$ pombe ABD are located 301 to loops connecting the helices (Figure 10).

302 The predicted structure of the Bigelowiella ROD domain is similar to all other determined 303 spectrin repeats although the sequence identity in general is low (Figure 11). When the amino 304 acid sequence is compared to one of the templates used in the prediction, the rod domain of 305 human $\alpha$-actinin (pdb: 1hci), the sequence identity of either of the four repeats is around $20 \%$ or 306 less (Figure 12). Still the Z-scores and rmsd values range from 11.7 to 14.3 and 1.6 to 2.5, 307 respectively, as determined by the DaliLite server.

308 Spectrin repeats are found in several cytoskeletal proteins, such as spectrin, dystrophin and 309 plectin as well as $\alpha$-actinins. The common structure of a spectrin repeat is a three-helix bundle. 
310 These repeats are defined by a tryptophan residue at position 17 in the first helix and a leucine

311 residue two residues from the C-terminal end of the third helix. This tryptophan is believed to be

312 essential for folding and stability of the triple-helix motif (Kusunoki et al. 2004; MacDonald et

313 al. 1994; Pantazatos \& MacDonald 1997). Interestingly, such a tryptophan is present in the

314 predicted ROD structure (Figure 11).

315 The central domain of Entamoeba histolytica $\alpha$-actinin 1 is also short, spanning ca 120 residues,

316 and probably does not form a spectrin repeat but rather a coiled structure (Virel \& Backman

317 2006). Since Entamoeba $\alpha$-actinin1, like Bigelowiella $\alpha$-actinin, cross-links actin filaments these

$318 \alpha$-actinins presumably dimerises by homotypic interactions between the central domain whether

319 it is a spectrin repeat or not. In contrast, in $\alpha$-actinins with four spectrin repeats dimerization

320 occurs by heterotypic interactions between the first and last and between the second and third

321 spectrin repeat (Djinovic-Carugo et al. 1999; Flood et al. 1995; Flood et al. 1997).

322 When the predicted structure of shortEF was submitted to the Dali server, the returned top-scorer

323 was the C-terminal calmodulin-like domain of Entamoeba histolytica $\alpha$-actinin2 (pdb: 2m71),

324 with a Z-score of 18.0 and a rmsd of $0.9 \AA$ (Figure 13). The same structure was also found when

325 EF was used as query.

\section{Conclusion}

327 I have cloned, expressed, isolated and characterized a Bigelowiella protein with all

328 characteristics of an $\alpha$-actinin. Structural and functional annotation by Superfamily (Wilson et al.

329 2009) identified a N-terminal calponin-homology domain, a C-terminal EF-hand domain and a

330 single spectrin repeat between the terminals. Direct binding assays as well as transmission

331 electron microscopy showed that the protein cross-links actin filaments into dense bundles.

332 Although experiments to localize the actin-binding site were impossible due to the protein's

333 propensity to precipitate, it is very likely that binding occurs to the N-terminal and the calponin

334 homology domain, as in other $\alpha$-actinins. Since both the full-length protein and the two C-

335 terminal constructs bound calcium, it is apparent that the calcium-affinity is due to one (or more) 
336 of the EF-hand motifs. Since only the first EF-hand motif has the proper residues required for

337 coordination of the calcium ion, it is probable that this motif also is responsible for the calcium

338 binding, similar to the calmodulin-like domain of human $\alpha$-actinin1 (Drmota Prebil et al. 2016).

339 Although some residues occurred in the disallowed regions of the Ramachandran plots, the

340 quality of the predicted structures were high and very similar to known $\alpha$-actinin domain

341 structures. Major differences in all domain models were located to loop regions.

342 Based on the experimental results as well as on the homology modelling, is it evident that this

343 Bigelowiella protein is a genuine $\alpha$-actinin.

344 It has been suggested that the rod domain in $\alpha$-actinin may function as a platform coordinating

345 interactions with structural and signalling proteins (Djinovic-Carugo et al. 2002). Since the rod

346 domain in Bigelowiella $\alpha$-actinin spans only one spectrin repeat, in contrast to four repeats in $\alpha$ -

347 actinins from multicellular organisms, less surface area is available for such a function. Alpha-

348 actinin has been implicated in several cellular functions, such as cytokinesis (Fujiwara et al.

349 1978; Li et al. 2016), movement (Matsudaira 1994; Meacci et al. 2016; Sobue \& Kanda 1989)

350 and contraction (Gautel \& Djinovic-Carugo 2016; Maruyama \& Ebashi 1965). Whether

351 Bigelowiella $\alpha$-actinin has similar functions requires further studies.

352

353 References

354 Archibald JM, Rogers MB, Toop M, Ishida K, and Keeling PJ. 2003. Lateral gene transfer and

355 the evolution of plastid-targeted proteins in the secondary plastid-containing alga

356 Bigelowiella natans. Proc Natl Acad Sci U S A 100:7678-7683. 10.1073/pnas.1230951100

357 Bhattacharya A, Tejero R, and Montelione GT. 2007. Evaluating protein structures determined

358 by structural genomics consortia. Proteins: Structure, Function, and Bioinformatics 66:778-

$359795.10 .1002 /$ prot.21165 
360 Blanchard A, Ohanian V, and Critchley D. 1989. The structure and function of $\alpha$-actinin. Journal 361 of Muscle Research and Cell Motility 10:280-289.

362 Broderick MJ, and Winder SJ. 2005. Spectrin, a-actinin, and dystrophin. Advances in Protein 363 Chemistry 70:203-246.

364 Curtis BA, Tanifuji G, Burki F, Gruber A, Irimia M, Maruyama S, Arias MC, Ball SG, Gile GH, 365 Hirakawa Y, Hopkins JF, Kuo A, Rensing SA, Schmutz J, Symeonidi A, Elias M, Eveleigh 366 RJ, Herman EK, Klute MJ, Nakayama T, Obornik M, Reyes-Prieto A, Armbrust EV, Aves SJ,

367 Beiko RG, Coutinho P, Dacks JB, Durnford DG, Fast NM, Green BR, Grisdale CJ, Hempel F, 368 Henrissat B, Hoppner MP, Ishida K, Kim E, Koreny L, Kroth PG, Liu Y, Malik SB, Maier 369 UG, McRose D, Mock T, Neilson JA, Onodera NT, Poole AM, Pritham EJ, Richards TA, 370 Rocap G, Roy SW, Sarai C, Schaack S, Shirato S, Slamovits CH, Spencer DF, Suzuki S, 371 Worden AZ, Zauner S, Barry K, Bell C, Bharti AK, Crow JA, Grimwood J, Kramer R, 372 Lindquist E, Lucas S, Salamov A, McFadden GI, Lane CE, Keeling PJ, Gray MW, Grigoriev 373 IV, and Archibald JM. 2012. Algal genomes reveal evolutionary mosaicism and the fate of 374 nucleomorphs. Nature (London) 492:59-65. 10.1038/nature11681

375 Djinovic-Carugo K, Gautel M, Ylanne J, and Young P. 2002. The spectrin repeat: a structural 376 platform for cytoskeletal protein assemblies. FEBS Letters 513:119-123.

377 Djinovic-Carugo K, Young P, Gautel M, and Saraste M. 1999. Structure of the a-actinin rod: 378 Molecular basis for cross-linking of actin filaments. Cell 98:537-546.

379 Dos Remedios CG, Chhabra D, Kekic M, Dedova IV, Tsubakihara M, Berry DA, and Nosworthy 380 NJ. 2003. Actin binding proteins: regulation of cytoskeletal microfilaments. Physiological 381 Reviews 83:433-473.

382 Drmota Prebil S, Slapsak U, Pavsic M, Ilc G, Puz V, de Almeida Ribeiro E, Anrather D, Hartl 383 M, Backman L, Plavec J, Lenarcic B, and Djinovic-Carugo K. 2016. Structure and calcium- 
384 binding studies of calmodulin-like domain of human non-muscle alpha-actinin-1. Scientific

385 Reports 6:27383. 10.1038/srep27383

386 Finn RD, Coggill P, Eberhardt RY, Eddy SR, Mistry J, Mitchell AL, Potter SC, Punta M,

387 Qureshi M, Sangrador-Vegas A, Salazar GA, Tate J, and Bateman A. 2016. The Pfam protein

388 families database: towards a more sustainable future. Nucleic Acids Research 44:D279-D285.

$38910.1093 /$ nar/gkv1344

390 Flood G, Kahana E, Gilmore AP, Rowe AJ, Gratzer WB, and Critchley DR. 1995. Association of

391 structural repeats in the a-actinin rod domain. Alignment of inter-subunit interactions. Journal 392 of Molecular Biology 252:227-234.

393 Flood G, Rowe AJ, Critchley DR, and Gratzer WB. 1997. Further analysis of the role of spectrin 394 repeat motifs in alpha-actinin dimer formation. European Biophysics Journal 25:431-435.

395 Foley KS, and Young PW. 2014. The non-muscle functions of actinins: an update. Biochemical 396 Journal 459:1-13. 10.1042/BJ20131511

397 Fujiwara K, Porter ME, and Pollard TD. 1978. Alpha-actinin localization in the cleavage furrow 398 during cytokinesis. Journal of Cell Biology 79:268-275.

399 Gautel M, and Djinovic-Carugo K. 2016. The sarcomeric cytoskeleton: from molecules to 400 motion. Journal of Experimental Biology 219:135-145. 10.1242/jeb.124941

401 Geiger B, Avnur Z, Rinnerthaler G, Hinssen H, and Small VJ. 1984. Microfilament-organizing 402 centers in areas of cell contact: cytoskeletal interactions during cell attachment and 403 locomotion. Journal of Cell Biology 99:83s-91s.

404 Gilson PR, Su V, Slamovits CH, Reith ME, Keeling PJ, and McFadden GI. 2006. Complete 405 nucleotide sequence of the chlorarachniophyte nucleomorph: nature's smallest nucleus. 406 Proceedings of the National Academy of Sciences of the United States of America 103:9566407 9571. 10.1073/pnas.0600707103 
408 Gould SB, Waller RF, and McFadden GI. 2008. Plastid evolution. Annu Rev Plant Biol 59:491$409 \quad$ 517. 10.1146/annurev.arplant.59.032607.092915

410 Hamill KJ, Hiroyasu S, Colburn ZT, Ventrella RV, Hopkinson SB, Skalli O, and Jones JC. 2015. 411 Alpha actinin-1 regulates cell-matrix adhesion organization in keratinocytes: consequences 412 for skin cell motility. Journal of Investigative Dermatology 135:1043-1052.

$413 \quad 10.1038 /$ jid.2014.505

414 Hasegawa H, and Holm L. 2009. Advances and pitfalls of protein structural alignment. Current 415 Opinion in Strutural Biology 19:341-348. 10.1016/j.sbi.2009.04.003

416 Kallberg M, Wang H, Wang S, Peng J, Wang Z, Lu H, and Xu J. 2012. Template-based protein 417 structure modeling using the RaptorX web server. Nature Protocols 7:1511-1522.

$418 \quad 10.1038 /$ nprot.2012.085

419 Krabberød AK, Orr RJS, Bråte J, Kristensen T, Bjørklund KR, and Shalchian-Tabrizi K. 2017. 420 Single Cell Transcriptomics, Mega-Phylogeny, and the Genetic Basis of Morphological 421 Innovations in Rhizaria. Molecular Biology and Evolution 34:1557-1573.

$422 \quad 10.1093 / \mathrm{molbev} / \mathrm{msx} 075$

423 Kusunoki H, MacDonald RI, and Mondragon A. 2004. Structural insights into the stability and 424 flexibility of unusual erythroid spectrin repeats. Structure (Camb) 12:645-656.

425 Laemmli UK. 1970. Cleavage of structural proteins during the assembly of the head of 426 bacteriophage T4. Nature (London) 227:680-685.

427 Letunic I, Doerks T, and Bork P. 2015. SMART: recent updates, new developments and status in 428 2015. Nucleic Acids Research 43:D257-D260. 10.1093/nar/gku949

Li Y, Christensen JR, Homa KE, Hocky GM, Fok A, Sees JA, Voth GA, and Kovar DR. 2016. 430 The F-actin bundler alpha-actinin Ain1 is tailored for ring assembly and constriction during 431 cytokinesis in fission yeast. Molecular Biology of the Cell 27:1821-1833. 10.1091/mbc.E16$432 \quad 01-0010$ 
433 Ma J, Wang S, Zhao F, and Xu J. 2013. Protein threading using context-specific alignment 434 potential. Bioinformatics 29:i257-i265. 10.1093/bioinformatics/btt210

435 MacDonald RI, Musacchio A, Holmgren RA, and Saraste M. 1994. Invariant tryptophan at a 436 shielded site promotes folding of the conformational unit of spectrin. Proceedings of the 437 National Academy of Sciences of the United States of America 91:1299-1303.

438 Maruyama K, and Ebashi S. 1965. Alpha-actinin, a new structural protein from striated muscle. 439 II. Action on actin. Journal of Biochemistry 58:13-19.

440 Maruyama K, Mikawa T, and Ebashi S. 1984. Detection of calcium binding proteins by ${ }^{45} \mathrm{Ca}$ 441 autoradiography on nitrocellulose membrane after sodium dodecyl sulfate gel electrophoresis. 442 Journal of Biochemistry 95:511-519.

443 Matsudaira P. 1994. Actin crosslinking proteins at the leading edge. Seminars in Cell and 444 Developmental Biology 5:165-174.

445 McGough A. 1998. F-actin-binding proteins. Current Opinion in Strutural Biology 8:166-176.

446 Meacci G, Wolfenson H, Liu S, Stachowiak MR, Iskratsch T, Mathur A, Ghassemi S, Gauthier 447 N, Tabdanov E, Lohner J, Gondarenko A, Chander AC, Roca-Cusachs P, O'Shaughnessy B, 448 Hone J, and Sheetz MP. 2016. alpha-Actinin links extracellular matrix rigidity-sensing 449 contractile units with periodic cell-edge retractions. Molecular Biology of the Cell 27:3471$450 \quad 3479.10 .1091 / \mathrm{mbc} . \mathrm{E} 16-02-0107$

451 Neilson JAD, Rangsrikitphoti P, and Durnford DG. 2017. Evolution and regulation of 452 Bigelowiella natans light-harvesting antenna system. Journal of Plant Physiology. $453 \quad$ 10.1016/j.jplph.2017.05.019

454 Otey CA, and Carpen O. 2004. $\alpha$-actinin revisited: a fresh look at an old player. Cell Motility and 455 the Cytoskeleton 58:104-111. 
456 Pantazatos DP, and MacDonald RI. 1997. Site-directed mutagenesis of either the highly 457 conserved Trp-22 or the moderately conserved Trp-95 to a large, hydrophobic residue reduces 458 the thermodynamic stability of a spectrin repeating unit. Journal of Biological Chemistry $459 \quad 272: 21052-21059$.

460 Pardee JD, and Spudich JA. 1982. Purification of muscle actin. Methods In Enzymology $85 \mathrm{Pt}$ $461 \quad$ B:164-181.

462 Pettersen EF, Goddard TD, Huang CC, Couch GS, Greenblatt DM, Meng EC, and Ferrin TE. 463 2004. UCSF Chimera--a visualization system for exploratory research and analysis. Journal 464 of Computational Chemistry 25:1605-1612. 10.1002/jcc.20084

465 Rogers MB, Archibald JM, Field MA, Li C, Striepen B, and Keeling PJ. 2004. Plastid-targeting 466 peptides from the chlorarachniophyte Bigelowiella natans. Journal of Eukaryotic $467 \quad$ Microbiology 51:529-535.

468 Sjöblom B, Salmazo A, and Djinovic-Carugo K. 2008. $\alpha$-actinin structure and regulation. 469 Cellular and Molecular Life Sciences 65:2688-2701.

470 Sobue K, and Kanda K. 1989. Alpha-actinins, calspectin (brain spectrin or fodrin), and actin 471 participate in adhesion and movement of growth cones. Neuron 3:311-319.

472 Spudich JA, and Watt S. 1971. The regulation of rabbit skeletal muscle contraction. Biochemical 473 studies of the interaction of the tropomyosin-troponin complex with actin and the proteolytic 474 fragments of myosin. Journal of Biological Chemistry 246:4866-4871.

475 Virel A, Addario B, and Backman L. 2007. Characterization of Entamoeba histolytica $\alpha$-actinin2. $476 \quad$ Molecular and Biochemical Parasitology 154:82-89.

477 Virel A, and Backman L. 2004. Molecular evolution and structure of $\alpha$-actinin. Molecular $478 \quad$ Biology and Evolution 21:1024-1031. 
479 Virel A, and Backman L. 2006. Characterization of Entamoeba histolytica $\alpha$-actinin. Molecular $480 \quad$ and Biochemical Parasitology 145:11-17.

481 Virel A, and Backman L. 2007. A comparative and phylogenetic analysis of the $\alpha$-actinin rod 482 domain. Molecular Biology and Evolution 24:2254-2265.

483 Wachsstock DH, Schwarz WH, and Pollard TD. 1993. Affinity of $\alpha$-actinin for actin determines 484 the structure and mechanical properties of actin filament gels. Biophysical Journal 65:205485214.

486 Wasenius VM, A N, Lehto VP, and Saraste M. 1987. alpha-actinin and spectrin have common 487 structural domains. FEBS Letters 221:73-76.

488 Wehland J, Osborn M, and Weber K. 1979. Cell-to-substratum contacts in living cells: a direct 489 correlation between interference-reflexion and indirect-immunofluorescence microscopy 490 using antibodies against actin and alpha-actinin. Journal of Cell Science 37:257-273.

491 Wilson D, Pethica R, Zhou Y, Talbot C, Vogel C, Madera M, Chothia C, and Gough J. 2009. 492 SUPERFAMILY--sophisticated comparative genomics, data mining, visualization and 493 phylogeny. Nucleic Acids Research 37:D380-386. gkn762 [pii] 10.1093/nar/gkn762

494 Winder SJ, and Ayscough KR. 2005. Actin-binding proteins. Journal of Cell Science 118:651495654.

496 


\section{Table $\mathbf{1}$ (on next page)}

Domain assignments of Bigelowiella natans $\alpha$-actinin by Superfamily, Smart and Pfam.

The amino acid sequence of Bigelowiella natans a-actinin was submitted to Superfamily (Wilson et al. 2009) , Smart (Letunic et al. 2015) and Pfam (Finn et al. 2016) . 
1 Table 1. Domain assignments of Bigelowiella natans $\alpha$-actinin by Superfamily, Smart and Pfam.

\begin{tabular}{|c|c|c|c|c|c|c|}
\hline & \multicolumn{2}{|c|}{ Superfamily } & \multicolumn{2}{|c|}{ Smart } & \multicolumn{2}{|c|}{ Pfam } \\
\hline & Region & E-value & Region & E-value & Region & E-value \\
\hline Calponin homology domain & $14-254$ & $9.75 e-56$ & $26-131$ & $5.82 \mathrm{e}-12$ & $24-134$ & $6.6 e-16$ \\
\hline Calponin homology domain & - & - & $148-250$ & $1.84 \mathrm{e}-23$ & $146-256$ & $9.0 \mathrm{e}-25$ \\
\hline Spectrin repeat & $274-384$ & $3.7 \mathrm{e}-17$ & $279-392$ & $5.2 \mathrm{e}-2$ & - & - \\
\hline EF-hand & $372-488$ & $9.45 \mathrm{e}-14$ & $392-421$ & $4.4 \mathrm{e}-6$ & $392-420$ & $2.6 \mathrm{e}-6$ \\
\hline $\mathrm{Ca} 2+$-insensitive EF-hand & & & $459-520$ & $1.44 \mathrm{e}-8$ & $459-520$ & $4.1 \mathrm{e}-9$ \\
\hline
\end{tabular}


Table 2 (on next page)

Validation scores for the predicted structures using Protein Structure Validation Software. 
2 Table 2. Validation scores for the predicted structures using Protein Structure Validation Software.

\begin{tabular}{|c|c|c|c|c|c|c|c|c|}
\hline \multirow[b]{2}{*}{ Structure Quality Factors } & \multicolumn{2}{|c|}{$\mathrm{ABD}$} & \multicolumn{2}{|c|}{ ROD } & \multicolumn{2}{|c|}{$\mathrm{EF}$} & \multicolumn{2}{|c|}{ shortEF } \\
\hline & Mean score & Z-score & Mean score & Z-score & Mean score & Z-score & Mean score & Z-score \\
\hline Procheck G-factor (phi / psi only) & 0.21 & 1.14 & 0.57 & 2.56 & 0.07 & 0.59 & 0.02 & 0.39 \\
\hline Procheck G-factor (all dihedral angles) & 0.05 & 0.30 & 0.35 & 2.07 & -0.04 & -0.24 & -0.01 & -0.06 \\
\hline Verify3D & 0.45 & -0.16 & 0.31 & -2.41 & 0.24 & -3.53 & 0.30 & -2.57 \\
\hline ProsalI & 0.55 & -0.41 & 0.78 & 0.54 & & & 0.82 & 0.70 \\
\hline MolProbity clashscore & 124.94 & -19.91 & 83.22 & -12.76 & 119.69 & -19.01 & 96.20 & -14.98 \\
\hline \multicolumn{9}{|l|}{ Ramachandran Plot Summary from Procheck } \\
\hline Most favoured regions & $89.9 \%$ & & $91.1 \%$ & & $86.5 \%$ & & $88.9 \%$ & \\
\hline Additionally allowed regions & $7.9 \%$ & & $8.1 \%$ & & $10.7 \%$ & & $9.7 \%$ & \\
\hline Generously allowed regions & $0.9 \%$ & & $0.8 \%$ & & $2.2 \%$ & & $0.0 \%$ & \\
\hline Disallowed regions & $1.3 \%$ & & $0.0 \%$ & & $0.6 \%$ & & $1.4 \%$ & \\
\hline \multicolumn{9}{|c|}{ Ramachandran Plot Statistics from Richardson's lab } \\
\hline Most favoured regions & $95.2 \%$ & & $94.9 \%$ & & $93.9 \%$ & & $92.3 \%$ & \\
\hline Allowed regions & $2.4 \%$ & & $4.4 \%$ & & $4.6 \%$ & & $5.8 \%$ & \\
\hline Disallowed regions & $2.4 \%$ & & $0.7 \%$ & & $1.5 \%$ & & $1.9 \%$ & \\
\hline
\end{tabular}


Figure 1

Domain organization of Bigelowiella $\alpha$-actinin-like protein.

The full-length protein contains a N-terminal actin-binding domain (ABD), a central rod domain (ROD), composed of one spectrin repeat and a C-terminal calmodulin-like domain (EF and shortEF) with EF-hand motifs. The first amino acid residue (methionine) was removed in all constructs.
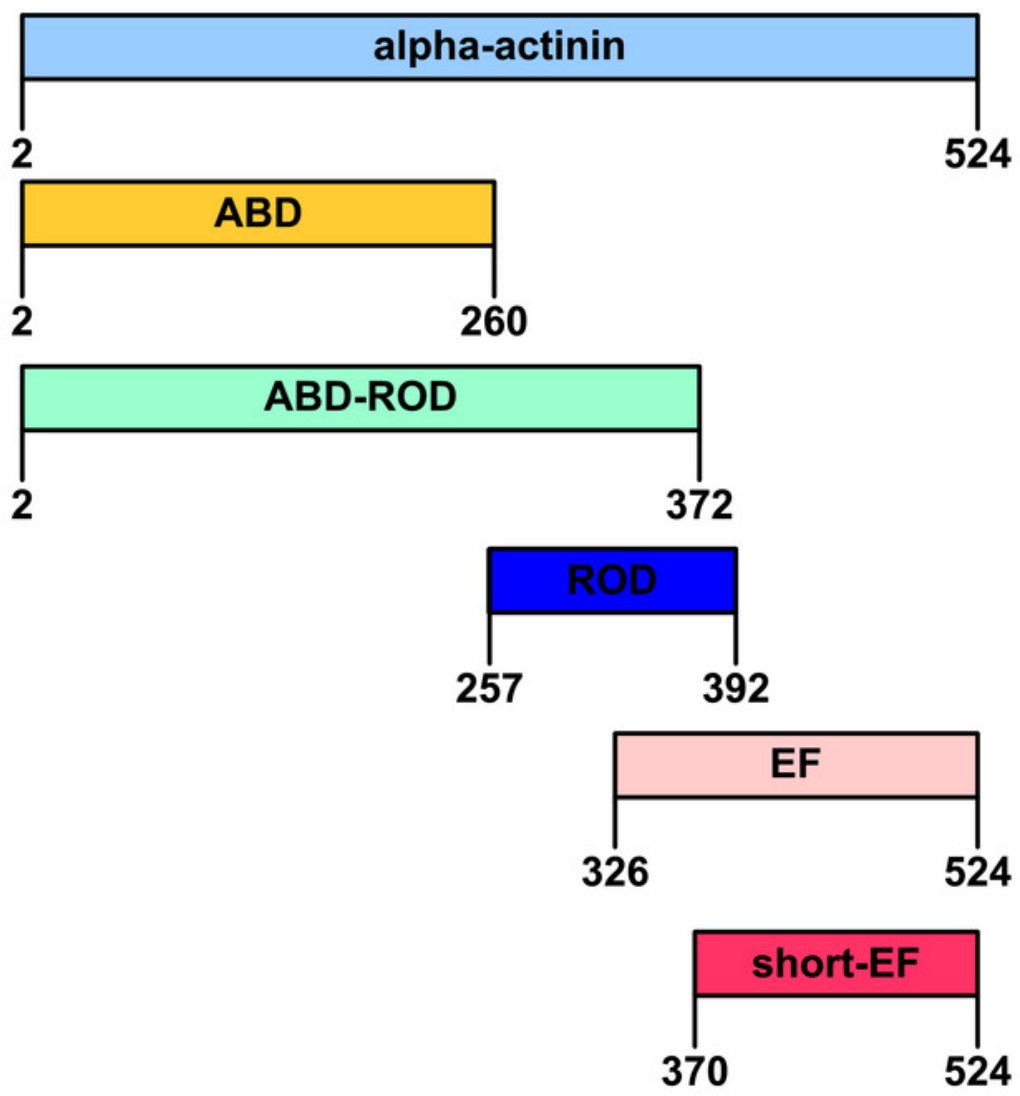
Figure 2

Gel filtration of Bigelowiella $\alpha$-actinin-like protein

(A) The oligomeric state of the full-length $\alpha$-actinin-like protein was determined by gel filtration on a Superdex 200 column, equilibrated with $50 \mathrm{mM}$ Tris, $200 \mathrm{mM} \mathrm{KCl}, 10 \mathrm{mM} \beta$ mercaptoethanol, 10\% glycerol, pH 8.0. $0.1 \mathrm{ml}$ His-tagged protein was applied after centrifugation at $343,000 \mathrm{xg}$ for $30 \mathrm{~min}$. The flow rate was $0.5 \mathrm{ml}$ per min and absorbance at 280 was measure continuously. Ferritin (440 kDa) and monomeric (67 kDa) and dimeric (135 $\mathrm{kDa})$ bovine serum albumin were used as references. $(B)$ Eluted fractions $(0.5 \mathrm{ml})$ were collected and analysed by gel electrophoresis. From left to right, the stained gel shows protein content of fractions eluted between 14 and $20 \mathrm{ml}$.

A

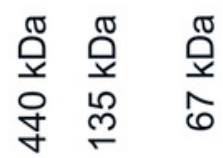

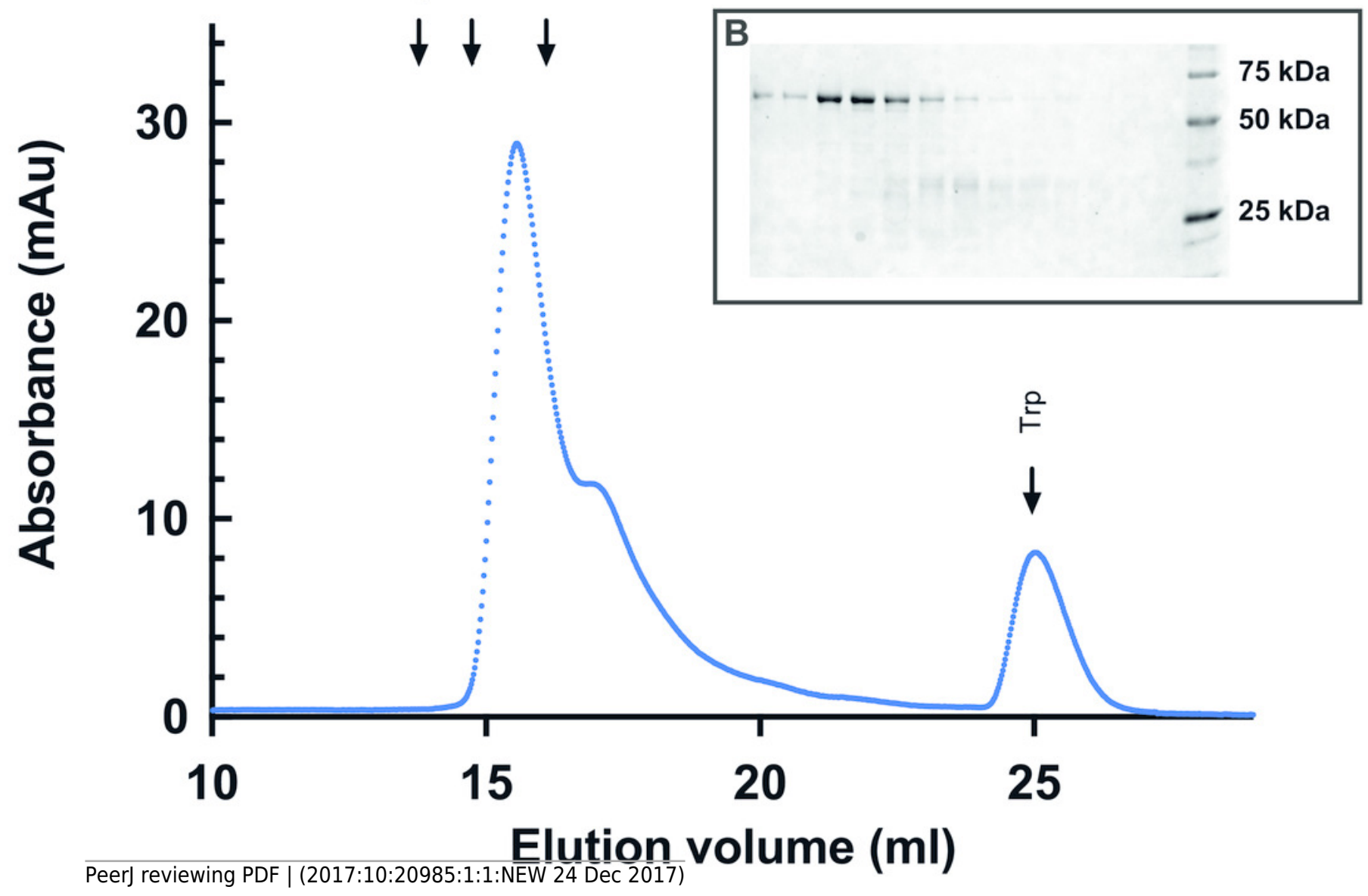


Figure 3

Gel filtration of Bigelowiella actin-binding domain (ABD)

Aggregation was analysed by gel filtration on a Toyopearl HW50-S 10/300 column, equilibrated with $50 \mathrm{mM}$ Tris, $200 \mathrm{mM} \mathrm{KCl}, 10 \mathrm{mM} \beta$-mercaptoethanol, 10\% glycerol, pH 8.0. $0.1 \mathrm{ml}$ His-tagged protein was applied direct after isolation (red) or after centrifugation at $343,000 \mathrm{xg}$ for $30 \mathrm{~min}$ (blue). The flow rate was $0.5 \mathrm{ml}$ per min and absorbance at $280 \mathrm{~nm}$ was measured continuously. Void volume was determined from the elution pattern of ferritin $(440 \mathrm{kDa})$. Data shown is representative of 3 independent experiments.

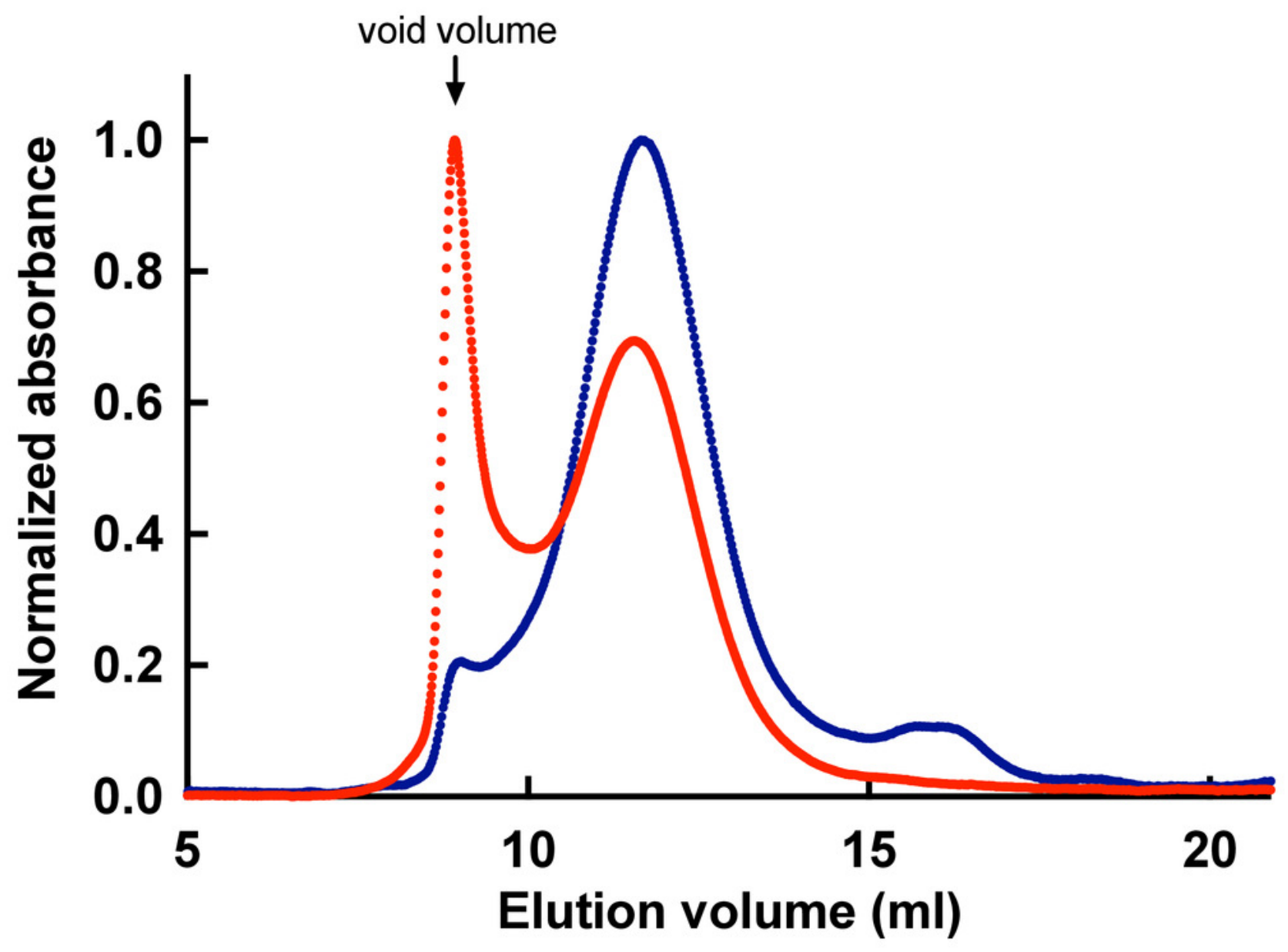


Figure 4

Calcium-binding properties of Bigelowiella $\alpha$-actinin-like protein.

Bigelowiella $\alpha$-actinin-like protein was slot-blotted onto a PVDF membrane, together with Entamoeba $\alpha$-actinin 1 (positive control) and S. pombe $\alpha$-actinin (negative control). Calciumbinding was probed by a calcium-overlay assay using ${ }^{45} \mathrm{Ca}$.

\section{$1.0 \mathrm{nmol}$ \\ $2.5 \mathrm{nmol}$ \\ $5.0 \mathrm{nmol}$}
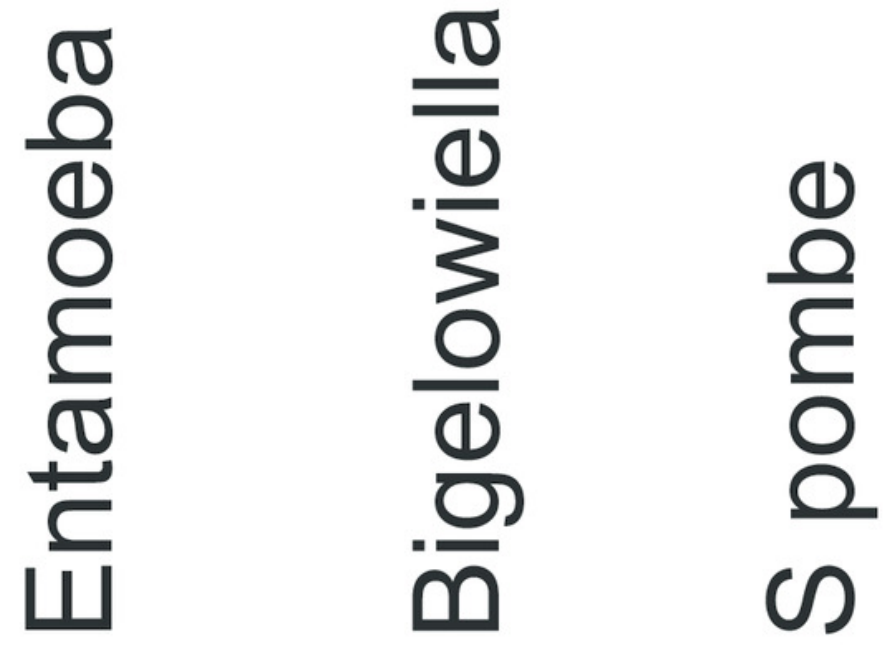


\section{Figure 5}

\section{Far UV-CD spectroscopy.}

(A) Far UV-CD spectra of the calmodulin-like C-terminal of Bigelowiella in the absence (red) and presence (blue) $10 \mathrm{mM}$ calcium ions. The mean residue molar ellipticity was determined from three accumulated scans between 200 and $260 \mathrm{~nm}$ at $20 \stackrel{\circ}{ } \mathrm{C}$, in $50 \mathrm{mM}$ Tris, pH 8.0. (B) Urea unfolding of the calmodulin-like C-terminal in the absence (red) and presence (blue) of $10 \mathrm{mM}$ calcium ions. The mean residue molar ellipiticy at $222 \mathrm{~nm}$ was determined from three accumulated scans between 200 and $260 \mathrm{~nm}$ at $20{ }^{\circ} \mathrm{C}$, in $50 \mathrm{mM}$ Tris, pH 8.0. (C) The terminal stability of the calmodulin-like C-terminal in the absence (red) and presence (blue) of $10 \mathrm{mM}$ calcium ions in $50 \mathrm{mM}$ Tris, $\mathrm{pH} 8.0$ and $2.9 \mathrm{M}$ urea was determined from the mean residue molar ellipticity at $222 \mathrm{~nm}$. 


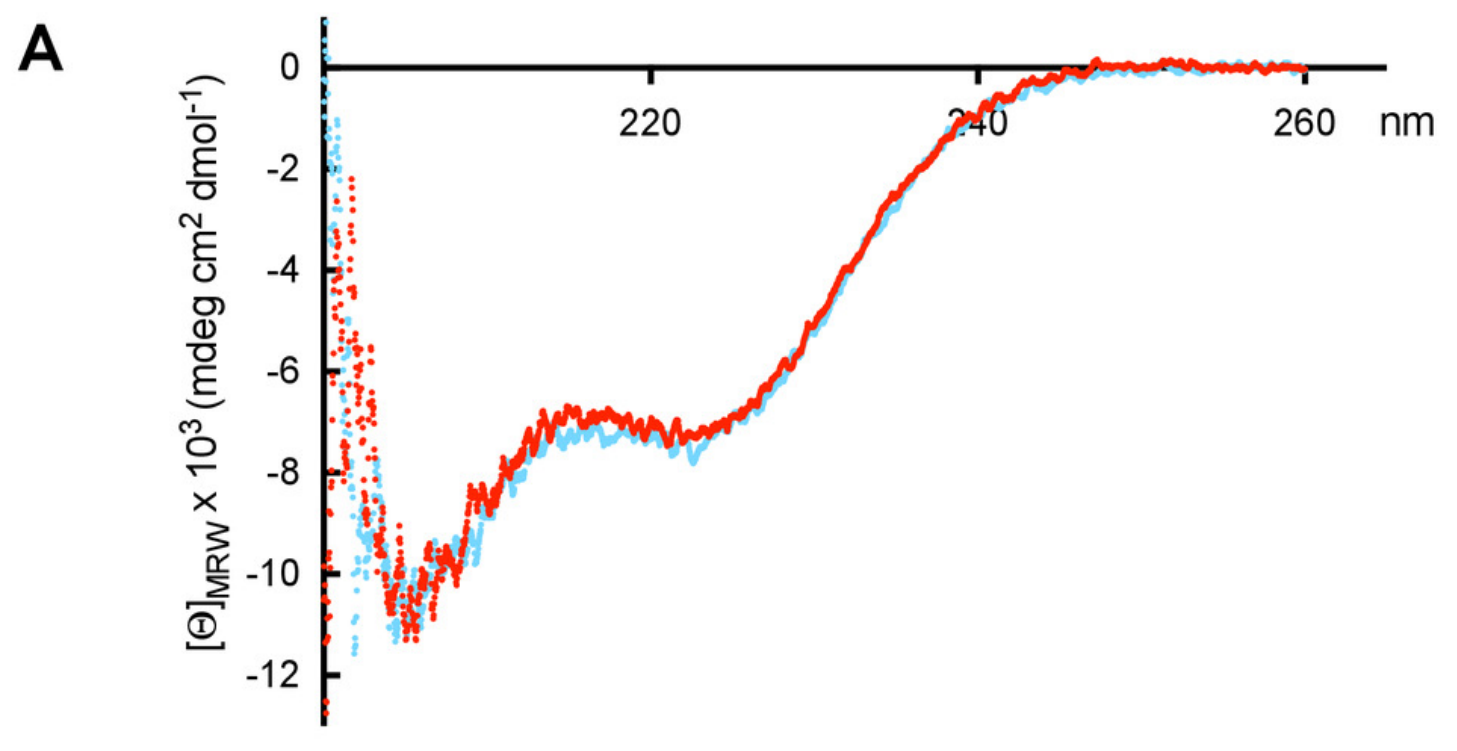

B

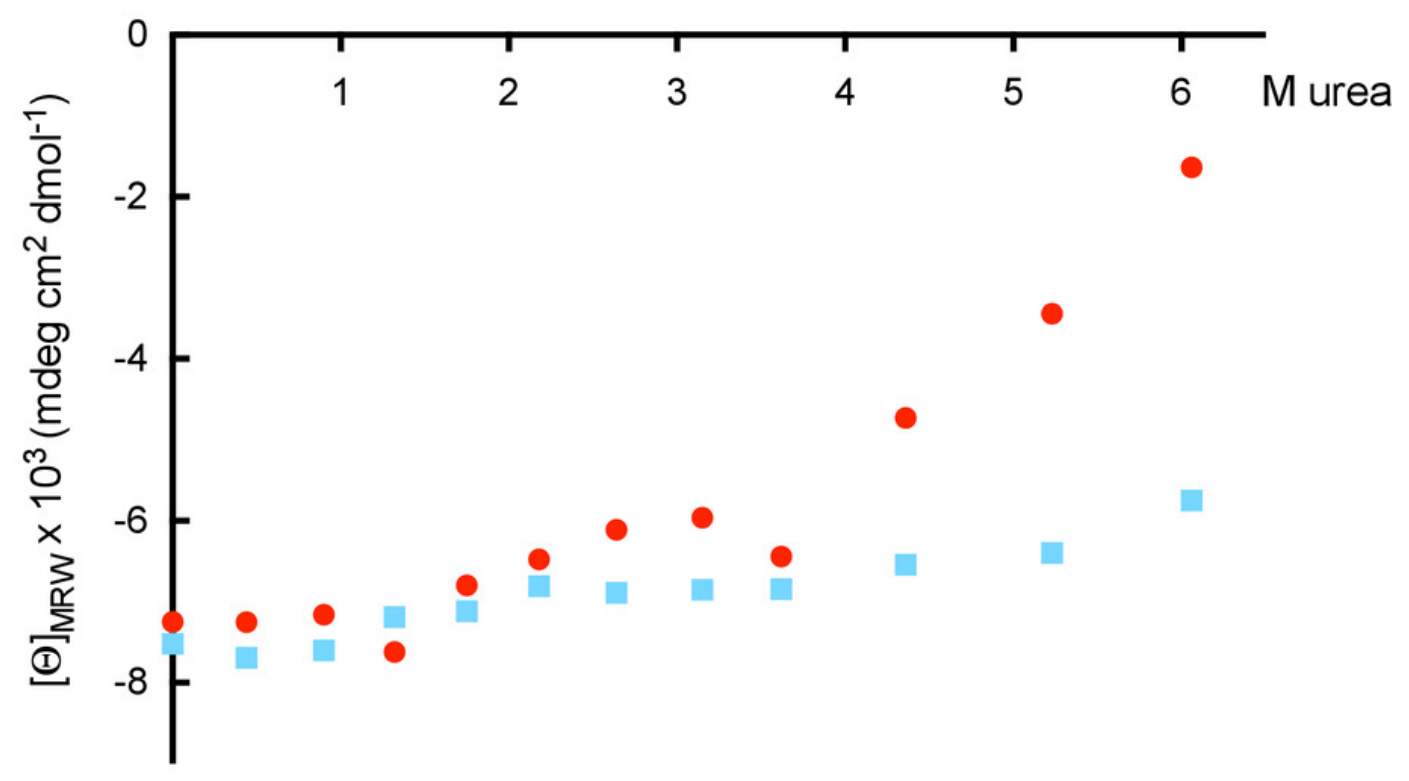

C

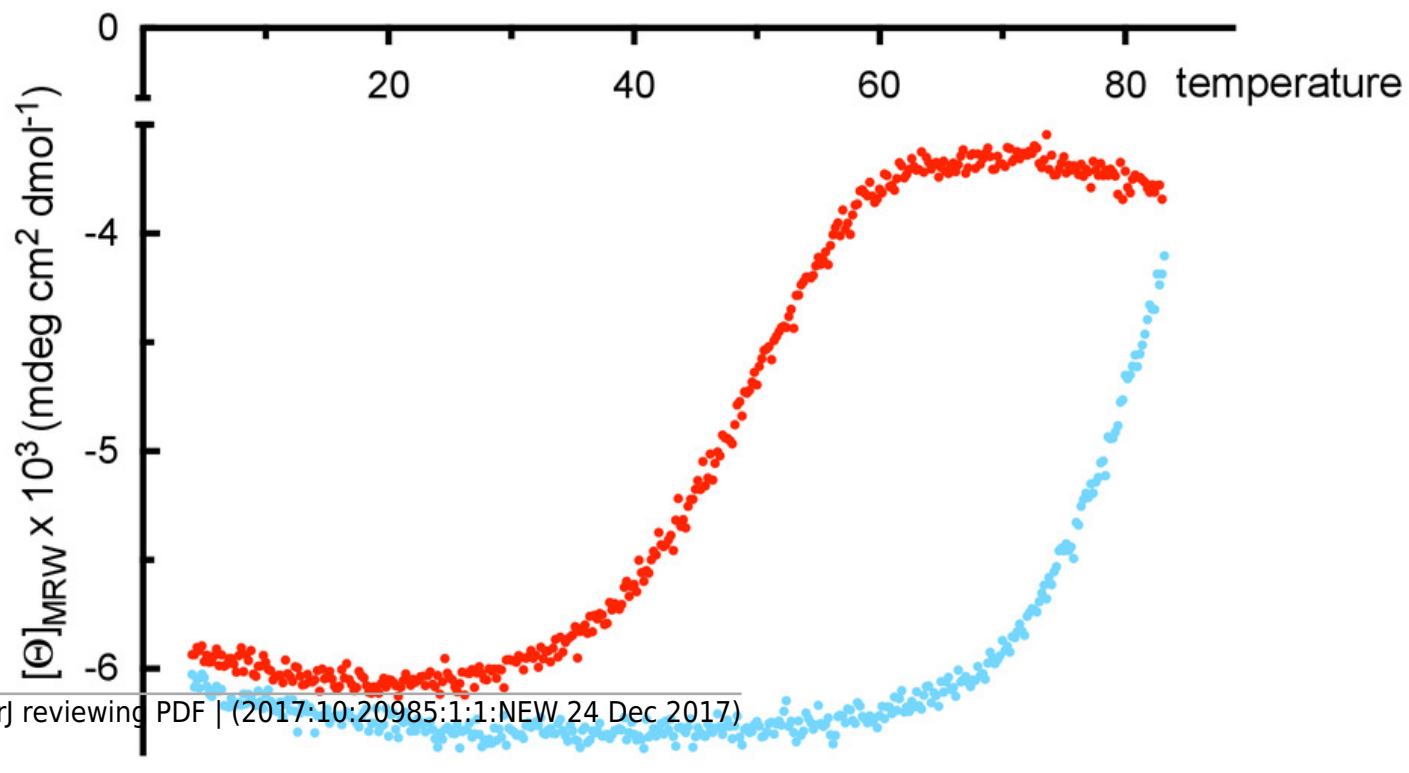




\section{Figure 6}

Calcium binding motifs.

The sequence of the calmodulin-like C-terminal domain of Bigelowiella a-actinin-like protein was aligned with C-terminal domains of other $\alpha$-actinins as well as with the canonical sequence. In the calcium binding loop residues at positions $X, Y, Z, y, x$ and $z$ coordinate the calcium ion, generally by side chain oxygens. The residue at position y coordinates the calcium ion through the backbone carbonyl oxygen. In the canonical sequence: E: glutamate; G: glycine; I: isoleucine, leucine or valine; $n$ : hydrophobic residue; *: any residue. Based on the Prosite PS00018 pattern: D-\{W\}-[DNS]-\{ILVFYW\}-[DENSTG]-[DNQGHRK]-\{GP\}-[LIVMC][DENQSTAGC]-x(2)-[DE]-[LIVNFYM], red indicates a residue present in active EF-hand motifs whereas blue indicates a residue not commonly found in this position of the calcium binding loop. 


\section{Figure 7}

Low speed actin co-sedimentation assay.

(A) Bigelowiella $\alpha$-actinin-like protein and polymerised actin were incubated for $30 \mathrm{~min}$ separately or together at different concentrations. After $30 \mathrm{~min}$ at room temperature, the samples were centrifuged (13,000 rpm, $15 \mathrm{~min}$ ) and supernatant (S) and pellet (P) were separated on 10\% SDS-PAGE and visualized by Coomassie Blue staining. Lane 1: $5 \mu \mathrm{M}$ actin; lanes 2-7: $5 \mu \mathrm{M}$ actin together with 2.5, 1, 0.5, 0.2, 0.1 and $0.05 \mu \mathrm{M} \alpha$-actinin-like protein; $\mathrm{M}$ : protein ladder. Data shown are representative of 3 experiments. (B) The fraction of actin pelleted by the presence of full-length $\alpha$-actinin-like protein was quantified by analysis of stained gels using Image Lab. 
A

$$
\frac{1}{S P} \frac{2}{S P} \frac{3}{S P} \frac{4}{S P} \frac{5}{S P} \frac{6}{S P} \frac{7}{S P} \frac{M}{-}
$$

$\alpha$-actinin

actin

B

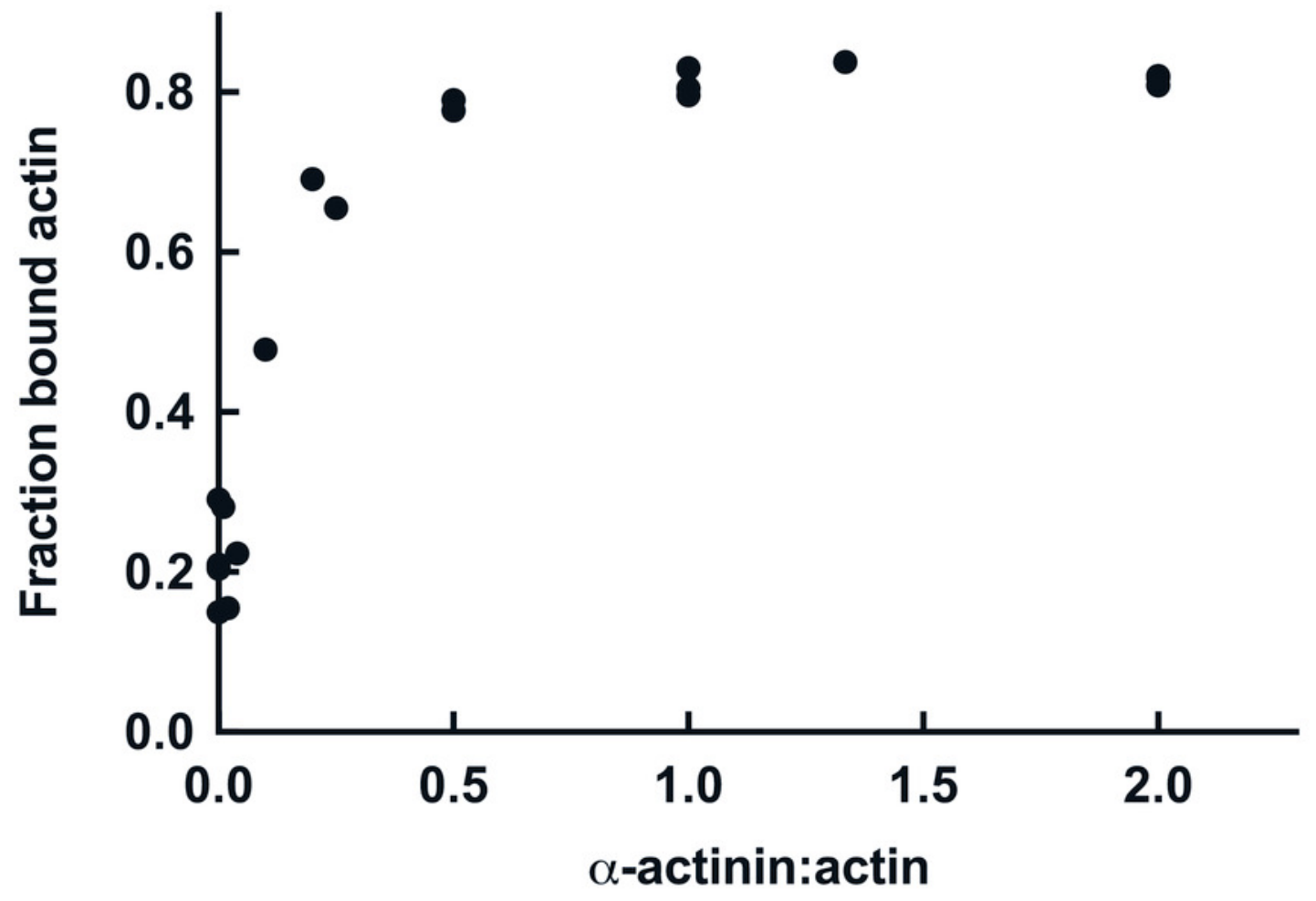




\section{Figure 8}

Electron transmission microscopy.

5.0 $\mu \mathrm{M}$ actin was incubated alone (A) or with $1.25 \mu \mathrm{M}$ Bigelowiella a-actinin-like protein (B) as before, added to grids and negatively stained with uranylacetate. Bar: $200 \mathrm{~nm}$.
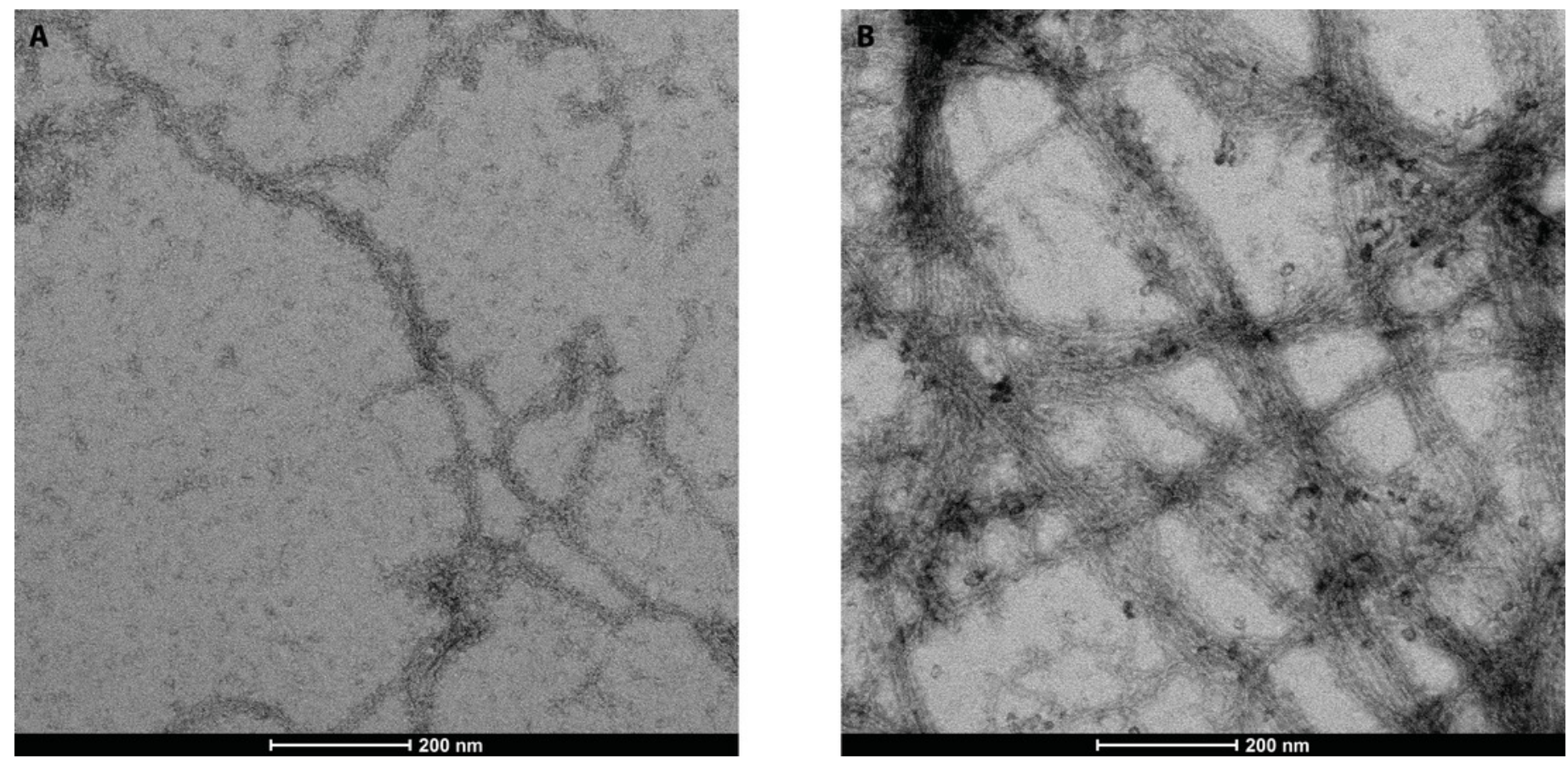


\section{Table 3(on next page)}

Ramachandran plot of the actin-binding domain (ABD) of Bigelowiella $\alpha$-actinin-like protein.

The quality of the predicted structure of ABD was analysed by Rampage. 6 residues (Lys38, Tyr40, Pro42, Thr144, Pro 165 and Val168) were found in disallowed regions. 


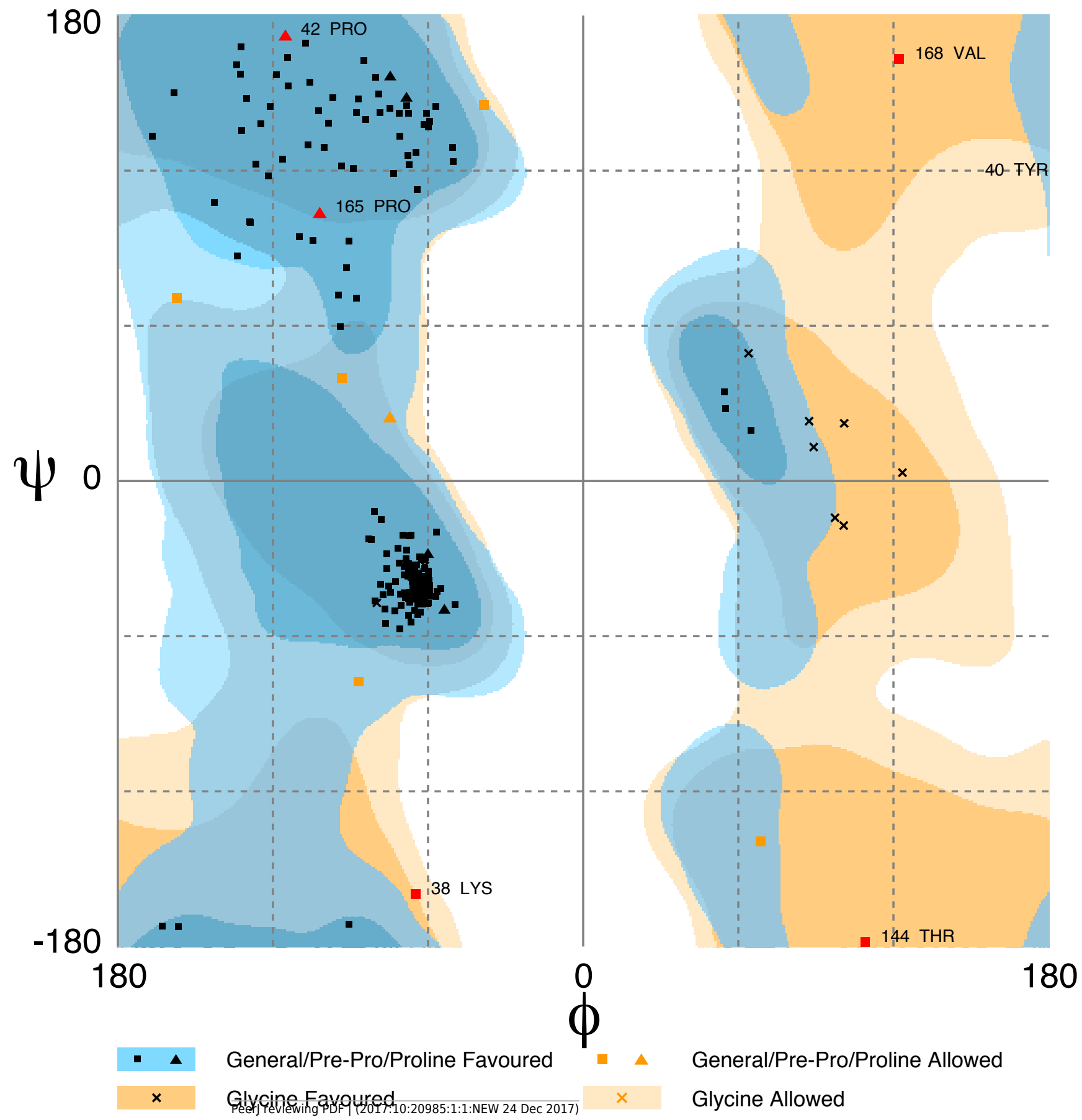


Figure 9

The actin-binding domai.

The predicted structure of actin-binding domain (ABD) of Bigelowiella $\alpha$-actinin-like protein (goldenrod) was superimposed with the crystal structure of S. pombe $\alpha$-actinin ABD (blue, pdb: 5bvr).

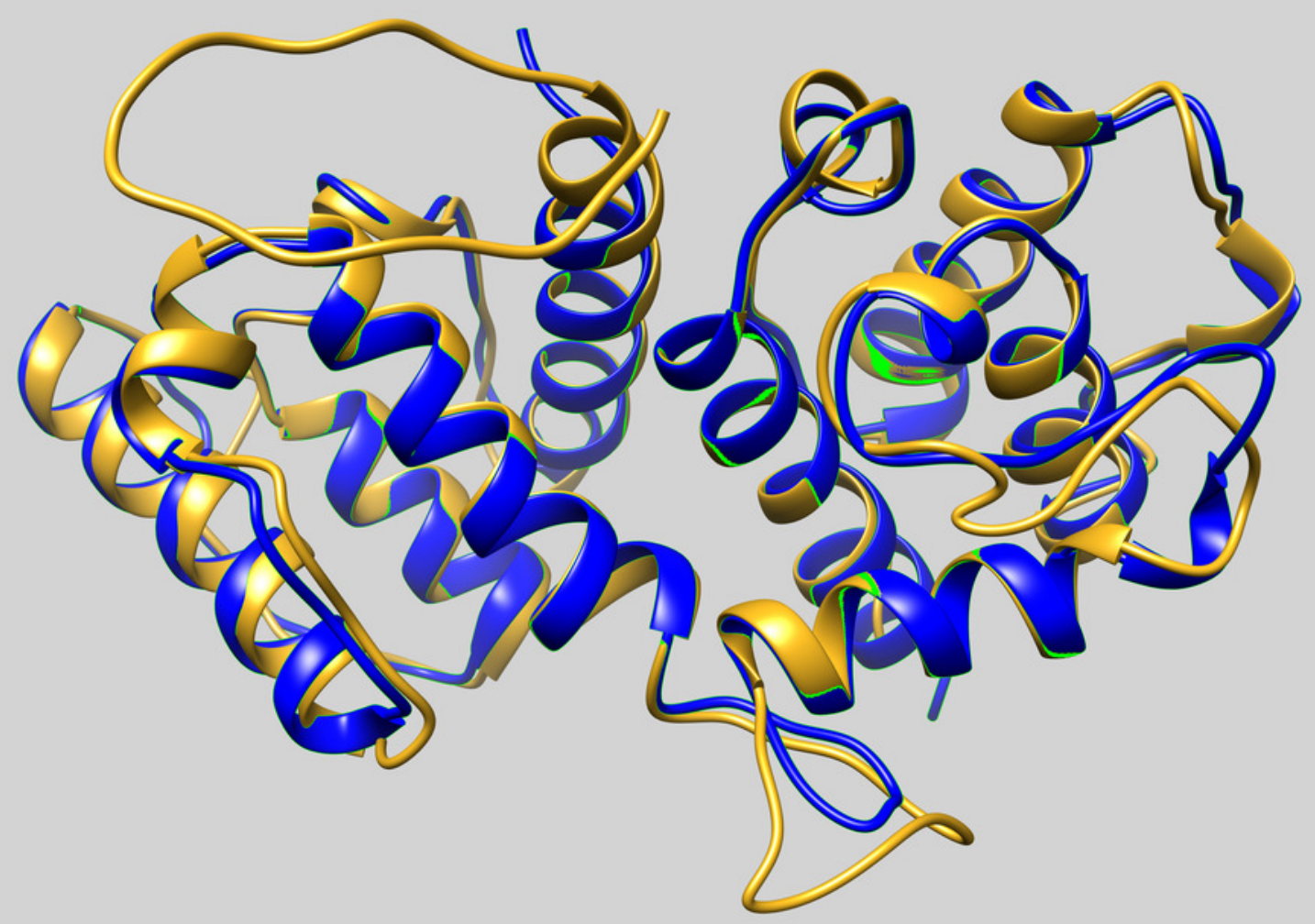




\section{Figure 10}

The rod domain.

The model of the rod domain of Bigelowiella $\alpha$-actinin-like protein (goldenrod) was superimposed with the first spectrin repeat of human $\alpha$-actinin2 (blue, pdb: 1hci). The characteristic tryptophan important for the stability of spectrin repeats is shown explicit.

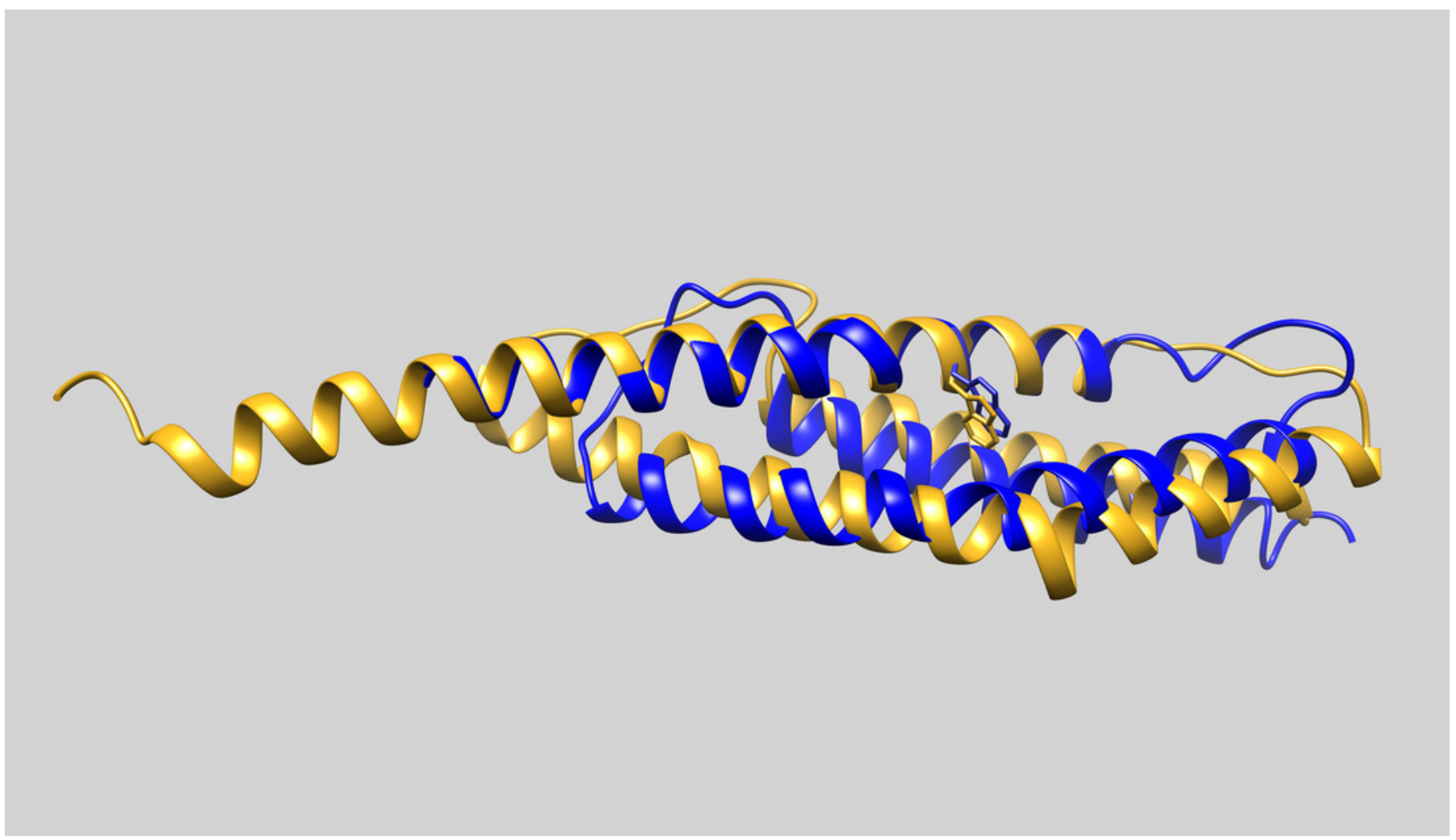




\section{Figure 11}

Alignment of the rod domain.

The sequences of human (accession: NM_001130004), Entamoeba histolytica (accessions:

AF208390 and XM_648191) and Schizosaccharomyces pombe (accession: NM_001019718) $\alpha$ actinins were aligned with Bigelowiella natans $\alpha$-actinin using Multalin (Corpet 1988) .

Shaded regions are predicted by JPred to be helical (Drozdetskiy et al. 2015) .

Human2

Bigelowiella

Entamoeba2

Pombe

Entamoeba1

Human2

Bigelowiella

Entamoeba2

Pombe

Entamoeba1
10

1 LGEKQAAVRRVKQFIAFQRQIWEQQNDYKARAETLMKWADGKISEYTKCDLGDTKEEVETGRSKLKEYLK NDQVEKAGKRAGNFLDFLRATEGMVHDYEQRAQALKENIEAAINKMNGVEPSDEYHQVKEQINETKNYRK LDKVETAARRVERFTEVLMSTHDMKIDYESRMKRLLGS IARMQEYWHTVQFENNYTDVKSHSNNFAKFKA REEQERKQKEEQERLAREEQERLAREEQERLAREEQERLAREEQERKQKEEQERLAREEQERKQREEQER

$\begin{array}{llllll}80 & 90 & 100 & 110 & 120 & 130\end{array}$

1

1

KHKPPKVQEKCQLEINFNTLQTKLRISNRPAFMPSEGKMVSDIAGAWQRLEQAEKGYEEWLLNEIR SVKPGKAVEKMDIESLYGEIQANLRINNRSPYCPPGSCAPNSLDSKWHELQQAEAKYKAT PEQLQE GDKRAFIKEQGDLATLFGQINSKLRGMKRPVYVAPEGLDPKSLEGYIANISEAERALRSKLNTAMR TEKREWVKEKIDLESLLGTIQTNLKTYQLRKYEPPAGLKIVDLERQWKDFLSEEANQSKLINTHMR LNQQQPTSQQLTFFSVQAAADAWILQNIQAAYAQDPTIQFQWWYPLVQNLSANDFRELQDWFKKID 


\section{Figure 12}

The calmodulin-like C-terminal domains.

The predicted structure of the calmodulin-like C-terminal domain (goldenrod) of Bigelowiella $\alpha$-actinin-like protein was superimposed with the $\mathrm{N}$-terminal (blue) and C-terminal (red) halves, respectively, of E. histolytica (pdb: $2 \mathrm{~m} 7 \mathrm{l}$ ).

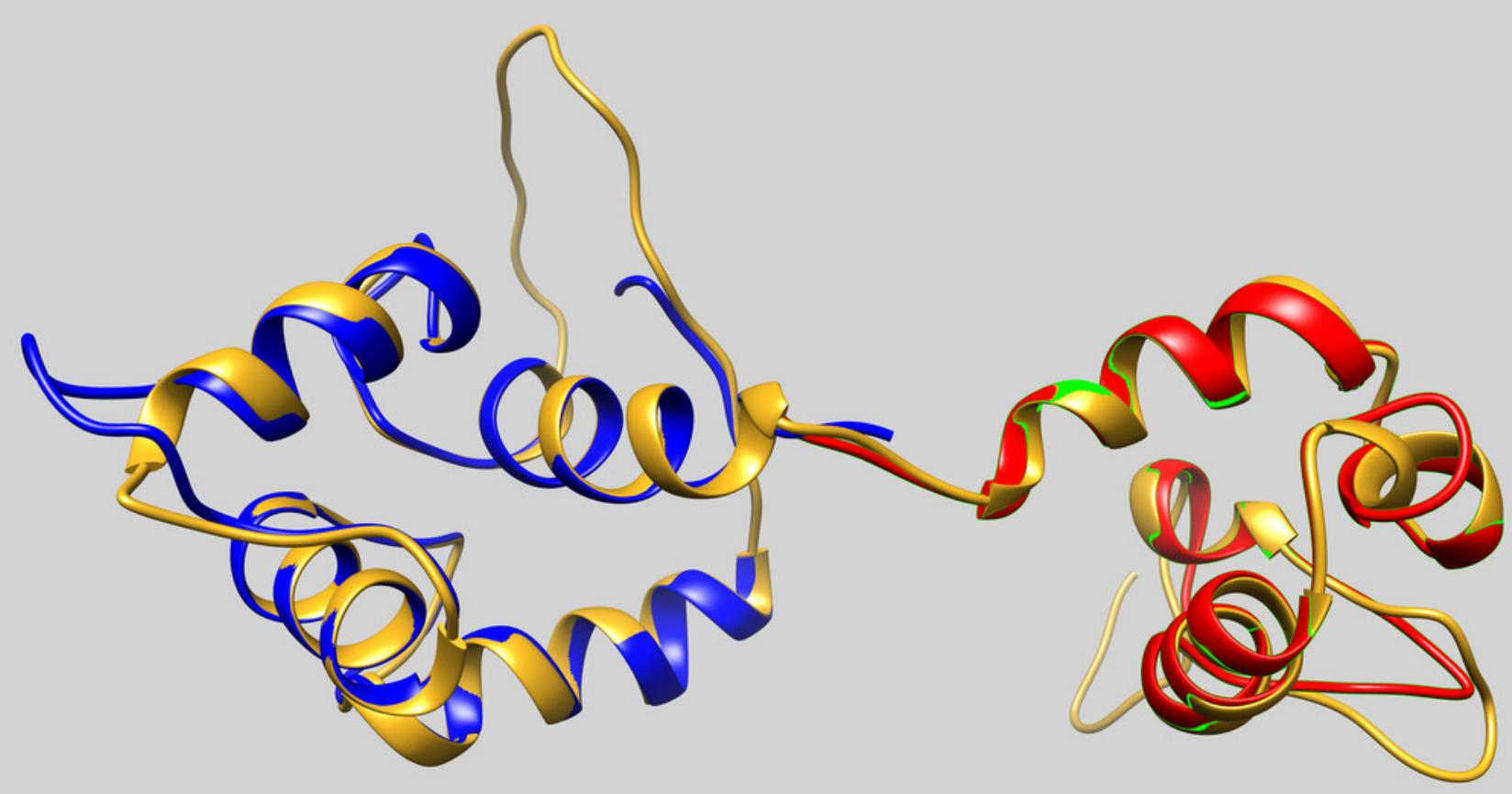

